\title{
Peran Pendidikan untuk Mengukuhkan Nasionalisme dan Membangun Karakter Bangsa
}

\author{
Edy Suandi Hamid \\ Fakultas Ekonomi Universitas Islam Indonesia (UII) \\ edysuandi@yahoo.com
}

\begin{abstract}
Nationalism as an ideological concept is considered to be one among important aspects in the creation of the character of the nation, including Indonesians. The character building for the nation in turn will determine the quality of the nation. The process of development within countries across the globe is partly shaped its success by the characters of the respective nation. The inception of such ideological concept c̈an be efficiently introduced through many channels, and education is a channel that can be utilized optimally to internalize the nationalism to the students' personality. It is considered therefore that certain ways of education that may support the internalization of such ideology need to be enhanced.
\end{abstract}

Key words: nationalism, education, character

\section{Pendahuluan}

Saat usia kemerdekaan Republik Indonesia menjelang tujuh puluh tahun, persoalan terkait nasionalisme masih sering muncul. Hal ini menjadi relevan dikaji dengan seringnya muncul konflik di beberapa daerah yang bernuansa kesukuan atau agama, ada adanya gerakan yang mengarah pada separatisme. Nasionalisme sebagai bagian integral dari wawasan kebangsaan pada dasarnya merupakan khazanah bangsa yang mengakar kuat sejak lama dalam kehidupan bangsa Indonesia. Sebagaimana pengalaman bangsa lain, nasionalisme terus tumbuh dan berkembang secara dinamis dan menjadi bagian dari sejarah bangsa ini (Purwanto, 2001). Sejak lama bangsa ini merasakan keterikatan satu sama lain untuk bersatu menuju tujuan bersama, yaitu kesejahteraan hidup. Buktinya berupa semangat bersama bangsa ini untuk bersatu mengusir penjajah yang diliputi perasaan senasib sepenanggungan untuk mencapai kehidupan merdeka yang lebih baik. Demi tujuan bersama tersebut, pengorbanan jiwa dan raga telah diberikan demikian banyaknya dan seolah menjadi tidak terasa demi kejayaan bersama. Hasil perjuangan berlandaskan semangat nasionalisme ini selanjutnya terkulminasi dalam. Proklamasi Kemerdekaan yang menandakan keberhasilan meraih cita-cita bersama.

Semangat nasionalisme ini pun masih nampak jelas dalam konteks perjuangan mempertahankan kemerdekaan dan masa-masa awal Republik ini berdiri. Bangsa Indonesia yang baru saja memproklamirkan diri sebagai bangsa merdeka, enggan untuk kembali ke dalam penjajahan bangsa lain. Untuk itulah, segenap upaya dilakukan untuk mempertahankan Republik dari keinginan bangsa lain untuk tetap bercokol di Indonesia. Bangsa ini pun berjuangan dengan segala pengorbanan yang pastinya sulit untuk dibayangkan oleh generasi yang hidup saat ini.Perjuangan tersebut memang akhirnya membawa hasil berupa pengakuan kedaulatan yang mempertegas keberadaan bangsa dan negara Indonesia hingga saat ini. 
Nasionalisme tidak hanya menjadi semangat yang membuat bangsa indonesia mampu berjuang mencapai dan mempertahankan kemerdekaannya dari bangsa lain.Lebih dari itu,nasionalisme telah menjadi perekat bangsa ini di saat sejumlah upaya merusak persatuan bangsa datang dari dalam bagian bangsa ini sendiri. Nasionalisme pada saat seperti itu telah menjadi penyelamat bangsa dan negara ini dari perpecahan berlatar belakang agama, etnis, maupun politik yang benihnya akan mudah dipupuk dalam bangsa multikultur seperti Indonesia saat ini. Semangat hidup bersama dalam satu wadah kebangsaan telah menjadikan keinginan sebagian kecil masyarakat untuk memisahkan diri dari keluarga besar bangsa seolah menjadi riak yang tidak berarti. Nasionalisme bahkan menjadi kompromi bersama untuk menjaga keutuhan bangsa dan melupakan, namun tanpa meniadakan, perbedaan yang ada.

Nasionalisme sejatinya juga dapat menjadi senjata ampuh dalam konteks kehidupan modern terutama di tengah arus globalisasi, terutama untuk mempertahankan identitas bangsa dari gempuran budaya asing. Nasionalisme dapat berfungsi untuk memberikan garis yang jelas antara budaya bangsa yang sesuai dengan perikehidupan masyarakat Indonesia dan budaya asing yang mengurangi rasa kebangsaan secara nasional. Nasionalisme dengan demikian diharapkan menjadi filter aktif yang membentengi bangsa dari gaya hidup ala bangsa lain yang tidak sesuai bahkan tidak konstruktif bagi pembangunan karakter bangsa.

Namun demikian, di balik besarnya peranan nasionalisme dalam menjaga kehidupan bangsa ini, sejumlah tantangan tetap terus hadir dan menjadi masalah tersendiri yang perlu menjadi perhatian. Keberagaman yang ada ternyata tidak selalu mampu menumbuhkan nasionalisme yang menjadi perekat semangat kebangsaan. Perbedaan terkadang dapat dengan mudah disulut menjadi pemicu konflik berlatar belakang agama, politik, etnis, maupun latar belakang lainnya. Akibatnya semangat nasionalisme berubah menjadi semangat chauvinisme sempit berdasarkan suku, agama, dan haluan politik. Rezim yang berkuasa pada saat yang sama seringkali lebih mengedepankan pendekatan militer dan politik sehingga konflik yang terjadi menjadi isu disintegrasi.

Untuk itulah, semangat nasionalisme menjadi urgen untuk kembali diwujudkan dalam kehidupan masyarakat di daerah konflik. Tujuannya adalah untuk mengembalikan solidaritas kebangsaan yang telah terkikis akibat adanya konflik berkepanjangan. Kajian singkat ini dimaksudkan untuk mengkaji upaya mengukuhkan kembali nasionalisme di daerah konflik, terutama melalui pembangunan karakter bangsa.

\section{Mengukuhkan Nasionalisme di Daerah Konflik}

Nasionalisme sebagaimana dijelaskan di awal, seringkali tercerabut dari masyarakat pada saat terjadi konflik. Konflik sendiri, terutama di negara berkembang memang menjadi pemandangan umum dan kesemuanya biasanya berakar dari isukeadilan dalam memperoleh kesejahteraan dalm penghidupan.Dalam konteks ini, paradoks global terjadi mengingat di satu sisi semangat menyatukan perbedaan politik, ekonomi, dan sosial terus terjadi, sebagiamana direfleksikan dalam penyatuan mata uang, zona ekonomi dan sebagainya, sedangkan pada sisi lainnya, keinginan untuk melepaskan diri dari kesatuan bangsa juga tumbuh subur karena kecemburuan sosial, perbedaan strata ekonomi, maupun faktor budaya lainnya (Mardiansyah, 2001).

Konflik, terutama yang melibatkan antar etnis, dalam konteks internasional terutama dipicu perubahan peta politik internasional, terutama pasca berakhirnya Perang Dingin. Selama Perang Dingin berlangsung, konfrontasi antara dua ideologi besar dunia, yaitu Liberal dan Komunis, mendominasi percaturan politik global, sehingga isu etnis seolah menghilang. Namun seiring berjalannya waktu, isu itu kembali muncul, terutama ditambahi dengan proses pembangunan ekonomi yang belum sepenuhnya menjamin pemerataan dan pencapaian yang menggembirakan (Perwita, 2006). 
Gambaran yang kurang lebih sama tentunya juga dapat dirujuk dalam konflik di Indonesia, yang marak terutama setelah berakhirnya Orde Baru dan transisi menuju Reformasi. Orde Baru dengan dominasi wajah militer dan pembangunannya terbukti mampu secara aktif meredam berbagai perbedaan dalam karakteristik bangsa Indonesia. Dalam rangka menjaga stabilitas, pendekatan keamanan dan kesejahteraan secara kasat mata seolah mampu menjadikan Indonesia lebih stabil dan aman. Namun mengingat fondasi militeristik dan pembangunan yang digunakan tidak mengakar, maka era kebebasan yang ditawarkan Reformasi seolah membuka kran ketidakpuasan yang selama ini terkekang. Belum mantapnya integrasi antara masyarakat asli dan pendatang, terutama melalui transmigrasi sebagai salah satu program Orde Baru, menjadikan isu putra daerah, suku, dan keturunan menjadi pemicu sejumlah konflik.

Isu agama pun cukup kerap menjadi pemicu konflik sebagaimana nampak di Ambon dan Poso. Selain masalah ketidakadilan ekonomi, sosial, dan politik sebagai penyebab utama, konflik di wilayah tersebut juga erat kaitannya dengan politik adu domba sebagai sisa-sisa penjajahan. Politik permukiman di Ambon yang secara lugas menjadikan masyarakat beda agama tersegregasi secara perlahan menjadi celah bagi munculnya isu perbedaan agama yang berdampak pada pecahnya konflik (Yuwono, 2008).Konflik yang terjadi juga sering berkembang seiring dengan tambahan peserta konflik dari luar daerah yang terpanggil semangat solidaritas sesama suku, agama, maupun sosial. Ditambah dengan lambannya penanganan oleh aparat, maka konflik yang terjadi pun makin cepat berubah dari yang sifatnya lokal dan spesifik menjadi bersifat masif (Cahyono, 2007).

Mengukuhkan kembali nasionalisme di daerah yang sebelumnya dilanda konflik tentu saja membutuhkan pekerjaan berat dan waktu yang lama.Dalam pikiran bawah sadarnya, masyarakat telah membentuk sentimen antar suku maupun agama yang demikian kuat dan sulit dihilangkan. Apalagi jika dikaitkan dengan kondisi psikologis anak dan remaja korban konflik, maka hambatan dari diri pribadi masyarakat sendiri sudah sangat kuat. Untuk itu, upaya ini memerlukan kerja keras dan kerjasama sebanyak mungkin pihak, tidak semata pemerintah, tetapi juga melibatkan pemuka masyarakat, tokoh agama, dan dunia pendidikan.

\section{Membangun Karakter Bangsa Melalui Pendidikan}

Masyarakat Indonesia sendiri pada dasarnya telah memiliki bekal karakter yang kuat dalam mengelola konflik. Masyarakat negeri Seith misalnya memiliki kesadaran adanya kemajemukan dengan berbagai dimensinya sekaligus potensi konflik dan disintegrasi di dalamnya, namun tetap diiringi dengan optimisme dalam mengelola kemajemukan berdasarkan filosofi Uliala-Leisiwa (Titaley, 2008). Masyarakat Dayak Kanayatn Kalimantan Barat misalnya juga memiliki hukum adat berbentuk adat badarah calah, adat badarah putih, dan adat na' manjaha sebagai media resolusi konflik. Selain itu, pranata adat pamabakng dan pati nyawa yang bersifat sakral-magis, juga berfungsi menyelesaikan konflik kekerasan (Bahari, 2007). Adanya sejumlah pranata adat yang mengarah pada upaya penyelesaian konflik di Indonesia ini menandakan bahwa secara alamiah bangsa ini memiliki semangat besar untuk hidup damai bersandingan dengan bangsa lain.

Kesadaran alamiah untuk hidup damai penuh kerukunan ini pada dasarnya merupakan modal utama dalam menguatkan karakter bangsa di tengah berbagai tantangan saat ini. Karakter bangsa yang harus dibangun terutama dalam kaitannya dengan globalisasi memang tidak terlepas dari semangat hidup damai tersebut. Realitas globalisasi yang menjadikan dunia menjadi global village mau tidak mau akan berimplikasi pada persaingan antar bangsa yang makin sengit. Dalam persaingan semacam ini, muncul pemahaman akan pentingnya membangun ketahanan nasional yang berbasis nasionalisme sebagai identitas yang inheren 
(Masrur, et.al., 2009). Tanpa nasionalisme sebagai karakter bangsa yang utama, niscaya akan sulit bagi bangsa Indonesia untuk maju dan mampu bersaing dengan bangsa lain secara bersama-sama.

Mengingat pentingnya membangun karakter bangsa tersebut, maka pendidikan karakter menjadi sesuatu yang mutlak harus ada. Pendidikan karakter sendiri biasa dimaknai sebagai upaya membantu peserta didik untuk memahami, peduli, dan berbuat atau bertindak berdasarkan nilai-nilai dan etika (Lickona dalam Elkind dan Sweet, 2004). Pandangan lain yang sejalan menegaskan bahwa pendidikan karakter adalah pendidikan budi pekerti, yaitu yang melibatkan aspek pengetahuan (cognitive), perasaan (feeling), dan tindakan (action) (Suyanto, 2010 dalam Anwas, 2010). Dalam kerangka praktik operasional pendidikan karakter adalah suatu proses pendidikan secara holistik yang menghubungkan dimensi moral dengan ranah sosial dalam kehidupan peserta didik sebagai pondasi bagi terbentuknya generasi yang berkualitas yang mampu hidup mandiri dan memiliki prinsip suatu kebenaran yang dapat dipertanggungjawabkan (Raharjo, 2010 dalam Anwas, 2010).

Dalam grand desain pendidikan karakter (Kemdiknas, 2010), pendidikan karakter merupakan proses pembudayaan dan pemberdayaan nilai-nilai luhur dalam lingkungan satuan pendidikan (sekolah), lingkungan keluarga, dan lingkungan masyarakat. Nilai-nilai luhur tersebut berasal dari: teori-teori pendidikan, psikologi pendidikan, nilai-nilai sosial budaya, ajaran agama, Pancasila dan UUD 1945 serta UU No 20 tahun 2003 tentang Sistem Pendidikan Nasional, serta pengalaman terbaik dan praktik nyata dalam kehidupan sehari-hari. Proses pembudayaan dan pemberdayaan nilai-nilai luhur tersebut juga perlu didukung oleh komitmen dan kebijakan pemangku kepentingan serta pihak-pihak terkait lainnya tèrmasúk dukungan sarana dan prasarana yang diperlukan.

Menanamkan pendidikan karakter tidak bisa dilakukan seperti mentransfer ilmu pengetahuan atau mengajarkan sesuatu pelajaran kepada peserta didik. Pendidikan karakter perlu bimbingan, keteladanan, pembiasaan, atau pembudayaan serta ditunjang oleh iklim lingkungan yang kondusif, baik di lingkungan keluarga, sekolah, dan masyarakat. Proses pembiasaan dan keteladanan melalui lingkungan yang kondusif ini kenyataannya tidak mudah: Orang tua, tokoh masyarakat, dan orang dewasa lainnya harus menjadi panutan bagi generasi muda. Dengan kata lain, peserta didik perlu contoh nyata menghayati dan mengamalkan norma dan nilai-nilai luhur serta akhlak mulia dalam kehidupan nyata sehari-hari di lingkungan mereka. Pendidikan karakter hakikatnya merupakan pengintegrasian antara kecerdasan, kepribadian, dan akhlak mulia.

Dalam konteks pendidikan Indonesia Pendidikan Pancasila dan Pendidikan Kewarganegaraan telah menjadi simbol dari upaya membangun karakter bangsa. Kedua mata pelajaran ini, dalam Undang-undang Pendidikan Tinggi yang disyahkan oleh DPR 13 Juli yang lalu, wajib dijarkan di perguruan tinggi, bersama mata pelajaran Bahasa Indonesia dan Agama. Kedua mata pelajaran atau mata kuliah ini, terutama setelah masa Reformasi seolah menjadi titik pusat pembelajaran karakter kebangsaan dari sejak pendidikan dasar hingga pendidikan tinggi. Keduanya memang memiliki posisi strategis, untuk membentuk watak, moral, dan jiwa bangsa. Namun demikian, menempatkan keduanya sebagai sumber utama untuk tugas berat ini jelas tidak memadai (Sapriya, 2007). Untuk itu, pengembangan lanjutan dari keduanya perlu terus dikembangkan terutama dikaitkan dengan karakter masyarakat di daerah konflik.

Pendidikan Pancasila dan Pendidikan Kewarganegaraan sebagai ujung tombak pendidikan karakter kebangsaan di tingkat formal, memiliki peranan penting dalammengenalkan karakter utama yang diperlukan bangsa Indonesia untuk dapat meraih kemerdekaan, mempertahankannya, dan mengisinya sehingga mampu bersaing dengan bangsa lain. Pada kedua mata pelajaran atau mata kuliah inilah, keragaman karakter bangsa dari sisi adat 
istiadat, budaya, agama, dan pemikiran politik seharusnya didialogkan untuk memberikan kesepahaman yang lebih mengakar., Bahwa Indonesia merupakan sebuah bangsa dengan latar belakang yang beragam sehingga memiliki potensi konflik harus dijelaskan sebagai sebuah keniscayaan. Pada saat yang sama, optimisme dan semangat persatuan juga terus dibangun dan dimunculkan sebagai solusi atas potensi konflik yang ada.

Karakter bangsa yang multikultur juga menjadi komponen yang harus dapat dihadirkan dalam kedua mata pelajaran atau mata kuliah ini. Karakter negara yang dibangun akan kesadaran sebagai negara bangsa yang mutikultur juga harus mewujud sehingga generasi muda menyadari bahwa perbedaan merupakan sesuatu yang inheren dalam kehidupan namun tetap memberi peluang dan celah bagi persatuan. Bhineka Tunggal Ika bersama dengan Negara Kesatuan Republik Indonesia, Undang-Undang Dasar 1945 beserta Pancasila didalamnya, dengan demikian harus dapat diinternalisasikan kepada peserta didik sebagai sebuah kesatuan yang membangun jati diri bangsa (Winataputra dan Saripudin, 2008).

\section{Penutup}

Pemaparan di atas menunjukkan bahwa dalam konteks berbangsa, perbedaan suku, agama, ras, politik, dan sosial merupakan sebuah keniscayaan yang senantiasa ada. Di masa lalu, perbedaan ini dapat dinihilkan mengingat sebagai bangsa, kita memiliki nasionalisme yang menggebu terutama dalam kaitannya dalam upaya merebut kemerdekaan. Perlahan, semangat nasionalisme ini mulai luntur dan sedikit demi sedikit dikalahkan oleh chauvisime sempit berlatar suku, agama, dan politik yang berujung pada konflik. Hal inj tentu saja sangat kontra produktif dengan semangat untuk bersaing di era globalisasi yang meniscayakan penguatan persatuan seluruh elemen bangsa. Dalam kondisi semacam inilah mengukuhkan nasionalisme menjadi kunci dalam membangun rekonsiliasi di daerah konflik, sekaligus perekat persatuan bangsa. Mengukuhkan nasionalisme pada dasarnya merupakan bagian penting dari proses membangun karakter bangsa yang diantaranya dilakukan melalui dunia pendidikan. Pendidikan karakter bangsa yang secara formal telah diakomodasi dalam sejumlah mata pelajaran atau mata kuliah harus dapat mewujudkan komitmen kebangsaan terhadap Bhineka Tunggal Ika, NKRI, UUD 1945, Pancasila sekaligus kesadaran akan adanya perbedaan dalam unsur pembentuk bangsa. Adanya perbedaan ini sekaligus menjadi pendorong optimisme persatuan bangsa.

\section{Daftar Pustaka}

Anwas, Oos M. (2010). "Televisi Mendidik Karakter Bangsa: Harapan dan Tantangan", Jurnal Pendidikan dan Kebudayaan Indonesia, Vol. 16, No. 3, hal. 256-266.

Bahari, Yohanes (2007). 'Model Resolusi Konflik Berbasis Pranata Adat pada Masyarakat Dayak Kanayatn di Kalimantan Barat', Wawasan: Jurnal Ilmu-ilmu Sosial, Vol. 13, No. 2, Hal. 92-104.

Cahyono, Heru (2007). 'Negara dan Masyarakat dalam Resolusi Konflik di Indonesia: Daerah Konflik Kalimantan Barat dan Kalimantan Tengah', Jurnal Penelitian Politik, Vol. 4, No. 1, hal. 71-78.

Mardiansyah, Arrochman (2001). 'Negara Bangsa dan Konflik Etnis: Nasionalisme vs EtnoNasionalisme', Jurnal IImu Sosial dan Politik, Vol. 4, No. 3, hal. 289-316.

Masrur, Masad, et.al. (2009). Kepemimpinan Pemuda yang Berbasis National Character Building", Jurnal Debat, Vol. 1, No. 1, Hal. 39-59. 
UNISIA, Vol. XXXIV No. 76 Januari 2012

Perwita, Anak Agung Banyu (1996). 'Konflik Antar Etnis dalam Masyarakat Global dan Relevansinya bagi Indonesia', Analisis CSIS, Vol. 25, No. 2, hal. 149-159.

Purwanto, Bambang (2001). 'Memahami Kembali Nasionalisme Indonesia', Jurnal IImu Sosial dan Politik, Vol. 4, No. 3, hal. 243-264.

Sapriya (2007), "Peran Pendidikan Kewarganegaraan dalam Membangun Karakter Warga Negara", Sekolah Dasar: Kajian Teori dan Praktik Pendidikan, Vol. 16, No. 1, hal. 22-34.

Titaley, Elsina (2008). 'Kemampuan Masyarakat Adat Negeri Seith untuk Mengelolah Potensi Konflik', Hipotesa: Jurnal Ilmu-ilmu Sosial, Vol. 2, No. 1, hal. 104-117.

Winataputra, Udin Saripudin dan Saripudin, Sumanah (2008). "Multikulturalisme-Bhinneka Tunggal Ika dalam Perspektif Pendidikan Kewarganegaraan Sebagai Wahana Pembangunan Karakter Bangsa Indonesia", Jurnal Pendidikan dan Kebudayaan, Vol. 14, No. 75, Hal. 1009-1027.

Yuwono, Dadung Budi (2008). 'Wayame: Gerakan Multikultural di Tengah Konflik Ambon', Harmoni: Jurnal Multikultural Multireligius, Vol. 7, No. 27, Hal. 13-43. 